\title{
Augmented renal clearance in septic patients and implications for vancomycin optimisation
}

\author{
João Pedro Baptista*, Eduardo Sousa, Paulo J. Martins, Jorge M. Pimentel \\ Serviço de Medicina Intensiva, Hospitais da Universidade de Coimbra, Praceta Professor Mota Pinto 3000-075, Coimbra, Portugal
}

\section{A R T I C L E I N F O}

\section{Article history:}

Received 11 November 2011

Accepted 13 December 2011

\section{Keywords:}

Creatinine clearance

Vancomycin

Continuous infusion

Therapeutic drug monitoring

Sepsis

\begin{abstract}
A B S T R A C T
The aim of this study was to evaluate the effect of augmented renal clearance (ARC) on vancomycin serum concentrations in critically ill patients. This prospective, single-centre, observational, cohort study included 93 consecutive, critically ill septic patients who started treatment that included vancomycin by continuous infusion, admitted over a 2-year period (March 2006 to February 2008). ARC was defined as 24h creatinine clearance $\left(\mathrm{CL}_{\mathrm{Cr}}\right)>130 \mathrm{~mL} / \mathrm{min} / 1.73 \mathrm{~m}^{2}$. Two groups were analysed: Group A, 56 patients with a $\mathrm{CL}_{\mathrm{Cr}} \leq 130 \mathrm{~mL} / \mathrm{min} / 1.73 \mathrm{~m}^{2}$; and Group B, 37 patients with a $\mathrm{CL}_{\mathrm{Cr}}>130 \mathrm{~mL} / \mathrm{min} / 1.73 \mathrm{~m}^{2}$. Vancomycin therapeutic levels were assessed on the first 3 days of treatment $\left(D_{1}, D_{2}\right.$ and $\left.D_{3}\right)$. Serum vancomycin levels on $\mathrm{D}_{1}, \mathrm{D}_{2}$ and $\mathrm{D}_{3}$, respectively, were $13.1,16.6$ and $18.6 \mu \mathrm{mol} / \mathrm{L}$ for Group $\mathrm{A}$ and $9.7,11.7$ and $13.8 \mu \mathrm{mol} / \mathrm{L}$ for Group B ( $P<0.05$ per day). The correlation between $\mathrm{CL}_{\mathrm{Cr}}$ and serum vancomycin on $\mathrm{D}_{1}$ was -0.57 $(P<0.001)$. ARC was strongly associated with subtherapeutic vancomycin serum concentrations on the first 3 days of treatment.
\end{abstract}

(C) 2012 Elsevier B.V. and the International Society of Chemotherapy. All rights reserved.

\section{Introduction}

Achieving an adequate serum concentration of antibiotic has been a challenge through the years. This challenge is greater when it is related to septic patients admitted to the Intensive Care Unit (ICU). Affected tissues are exposed to great metabolic and haemodynamic variations and these can lead to lower efficacy of antibiotics. The early phase of sepsis is often a hypermetabolic condition leading to increased renal blood flow, glomerular filtration rate (GFR), renal creatinine clearance and clearance of renally eliminated drugs, namely antibiotics [1-4]. This situation is usually ignored by clinicians; however, even though this is underassessed, it should be considered a major cause of treatment failure and emergence of bacterial resistance in critically ill septic patients. Vancomycin has been widely used for many years as a first-choice antibiotic for nosocomial infections due to Gram-positive bacteria. Despite readily available therapeutic drug monitoring (TDM), achieving the correct serum level can be a difficult task, particularly in severely septic patients, even with repeated loading doses and daily increments in perfusion rate, usually with higher doses than normally recommended.

The aim of this study was to evaluate the influence of augmented renal clearance (ARC) on serum vancomycin levels in a population of critical septic patients.

\section{Materials and methods}

This study was conducted at a 1427-bed teaching hospital belonging to the University of Coimbra (Hospitais da Universidade de Coimbra, Coimbra, Portugal). In total, 93 consecutive, ventilated, adult patients with severe sepsis or septic shock, according to accepted definitions [5], who started empirical or directed treatment that included vancomycin were prospectively enrolled over the 2-year period March 2006 to February 2008. Serum levels were evaluated on the first 3 days of treatment $\left(D_{1}, D_{2}\right.$ and $\left.D_{3}\right)$. Our vancomycin protocol starts with a loading dose, depending on the patient's actual weight, of $1000 \mathrm{mg}$ (body weight $\leq 70 \mathrm{~kg}$ ) or $1500 \mathrm{mg}$ (body weight $>70 \mathrm{~kg}$ ) over $1 \mathrm{~h}$, followed by continuous infusion $(30 \mathrm{mg} / \mathrm{kg} /$ day $)$ irrespective of the patient's $24-\mathrm{h}$ creatinine clearance $\left(\mathrm{CL}_{\mathrm{Cr}}\right)$. Thereafter, daily analysis of serum levels was performed, with $13.8-20.7 \mu \mathrm{mol} / \mathrm{L}$ considered the target level for adequate treatment for Gram-positive microorganisms, including lung infection [6]; if appropriate, dosage adjustment was performed on subsequent days. Vancomycin is stable for slow intravenous administration over a 24 -h period [7]. At Hospitais da Universidade de Coimbra, Staphylococcus aureus show no resistance to vancomycin [minimum inhibitory concentration $(\mathrm{MIC}) \leq 1 \mu \mathrm{g} / \mathrm{mL}]$.

ARC was defined as $\mathrm{CL}_{\mathrm{Cr}}>130 \mathrm{~mL} / \mathrm{min} / 1.73 \mathrm{~m}^{2}$ [8-11]. Body surface area (BSA) was measured, and $\mathrm{CL}_{\mathrm{Cr}}$ for the 93 patients and adjusted accordingly to create two groups, as follows: Group A (control group) with a $\mathrm{CL}_{\mathrm{Cr}} \leq 130 \mathrm{~mL} / \mathrm{min} / 1.73 \mathrm{~m}^{2}$ ( $N=56$ patients); and Group B (study group) with a $\mathrm{CL}_{\mathrm{Cr}}>130 \mathrm{~mL} / \mathrm{min} / 1.73 \mathrm{~m}^{2}(N=37$ patients). Simplified Acute Physiology Score II and Acute Physiology

\footnotetext{
* Corresponding author. Tel.: +351919484 262; fax: +351239402973.

E-mail address: joaopedrobaptista@gmail.com (J.P. Baptista).
} 
and Chronic Health Evaluation (APACHE) II score were recorded. Diuretic and vasoactive drug use were recorded on the first day of the study. Exclusion criteria for study admission were as follows: (i) renal replacement therapy; (ii) serum creatinine concentration $\left(\mathrm{S}_{\mathrm{Cr}}\right)>115 \mu \mathrm{mol} / \mathrm{L}$ on the first day of the study; (iii) time interval between loading dose and TDM of vancomycin $<12 \mathrm{~h}$; and (iv) pregnant women.

\subsection{Patient sampling and analytical assay}

Single serum and urinary creatinine, single blood urea nitrogen (BUN) and total serum proteins, albumin and vancomycin determinations were determined each morning (7:00-7:30 am) as part of the routine procedure in this unit, as well as the urine collection over a 24-h period.

Serum vancomycin concentrations were measured using a colorimetric turbidimetric immunoassay (PETINIA; Siemens Laboratories, Deerfield, IL). The limit of detection (LOD) was $0.8 \mu \mathrm{g} / \mathrm{mL}$ and the intra-assay coefficient of variation (CV) was between $2.4 \%$ and $5.3 \% . \mathrm{S}_{\mathrm{Cr}}$ and urinary creatinine concentration $\left(\mathrm{U}_{\mathrm{Cr}}\right)$ were automatically measured using alkaline picrate methodology. The normal $\mathrm{S}_{\mathrm{Cr}}$ reference range for adult males and females is $62-115 \mu \mathrm{mol} / \mathrm{L}$ and $53-97 \mu \mathrm{mol} / \mathrm{L}$, respectively. The LOD was $4.4 \mu \mathrm{mol} / \mathrm{L}$ for $\mathrm{S}_{\mathrm{Cr}}$ and $119 \mu \mathrm{mol} / \mathrm{L}$ for $\mathrm{U}_{\mathrm{Cr}}$; the imprecision of the creatinine assay was $<6 \%$ total CV for concentrations $>88.4 \mu \mathrm{mol} / \mathrm{L}$ and the standard deviation (S.D.) was $\leq 8.8 \mu \mathrm{mol} / \mathrm{L}$ for concentrations $\leq 88.4 \mu \mathrm{mol} / \mathrm{L}$. The BUN was determined automatically using urease methodology. The normal BUN reference range for adult males and females aged $>50$ years is $3-9.2 \mathrm{mmol} / \mathrm{L}$ and $3.5-7.2 \mathrm{mmol} / \mathrm{L}$, respectively, and is $3.2-7.4 \mathrm{mmol} / \mathrm{L}$ and 2.5-6.7 mmol/L in the remaining ages. The LOD for BUN was $0.25 \mathrm{mmol} / \mathrm{L}$; the imprecision of the BUN assay was $<4.5 \%$ total $\mathrm{CV}$. A photometric colour test for quantitative determination of total protein and albumin in human serum and plasma was performed on Hitachi chemistry analysers (Olympus Life and Material Science Europa GmbH, O'Callaghan's Mills, Ireland) according to the manufacturer's recommendations. The normal adult reference intervals are $66-83 \mathrm{~g} / \mathrm{L}$ and $35-52 \mathrm{~g} / \mathrm{L}$ for total protein and albumin, respectively.

\subsection{Statistical analysis}

Continuous variables are expressed as mean or median when applied, together with their dispersion coefficients (S.D. or interquartile range, respectively). Qualitative variables are presented as frequencies and percentages. For subgroup comparison, Student's $t$-test or Mann-Whitney $U$-test were used as indicated. The correlation between continuous variables was established using the Spearman coefficient $(r S)$. Multiple regression analyses were performed in order to examine confounding effects or interactions with age and sex. A $P$-value of $<0.05$ was considered statistically significant.

The results were analysed with the SPSS software package v.13.0 (SPSS Inc., Chicago, IL) and with MedCalc software v.9.3.8 for Windows (MedCalc Software, Mariakerke, Belgium).

\subsection{Formulae}

$\mathrm{CL}_{\mathrm{Cr}}$ was calculated according to formula: $\mathrm{CL}_{\mathrm{Cr}}=\left(\mathrm{U}_{\mathrm{Cr}} / \mathrm{S}_{\mathrm{Cr}}\right) \times(24-$ h urinary output/1440) $\times(1.73 / B S A)$. The DuBois and DuBois formula was used to calculate $\mathrm{BSA}$ : $\mathrm{BSA}=0.007184 \times[$ height $(\mathrm{cm})]^{0.725} \times[\text { weight }(\mathrm{kg})]^{0.425}$.

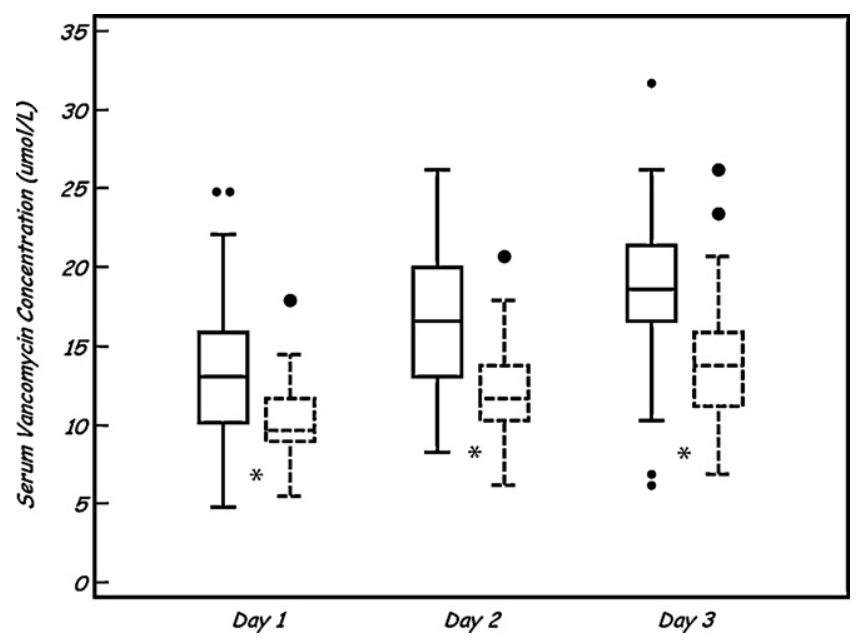

Fig. 1. Box and whisker plots showing the evolution of median (interquartile range) serum vancomycin concentrations on the studied days (Days 1-3) and comparison between Group A [control group without augmented renal clearance (ARC); continuous line] and Group B (study group with ARC; dashed line). * Indicates statistical significance for median differences $(P<0.01)$.

\section{Results}

The main characteristics and results of the 93 patients are shown in Table 1 . In this study, $40 \%$ of the patients showed ARC. These patients were significantly younger, less severely ill, with trauma as the leading cause of admission, and with lower BUN on the first day of the study (Table 1 ).

In Group A, 16 patients (28.6\%) were identified with $\mathrm{CL}_{\mathrm{Cr}}<60 \mathrm{~mL} / \mathrm{min} / 1.73 \mathrm{~m}^{2}$. The total amount of vancomycin and the time interval between the loading dose and TDM of vancomycin on $D_{0}$ (the day before the first serum level analysis) was equivalent in both groups (Table 2). The serum vancomycin concentration in Group B was significantly lower than in the control group for the 3 days of the study: $13.1 \mathrm{vs} .9 .7 \mu \mathrm{mol} / \mathrm{L}$ on $\mathrm{D}_{1}, 16.6 \mathrm{vs} .11 .7 \mu \mathrm{mol} / \mathrm{L}$ on $\mathrm{D}_{2}$ and $18.6 \mathrm{vs} .13 .8 \mu \mathrm{mol} / \mathrm{L}$ on $\mathrm{D}_{3}$ for Groups $\mathrm{A}$ and $\mathrm{B}$, respectively (Fig. 1). Only four patients belonging to Group B reached therapeutic levels ( $>13.8 \mu \mathrm{mol} / \mathrm{L}$ ) on $\mathrm{D}_{1}(4 / 37 ; 10.8 \%), 11$ patients on $\mathrm{D}_{2}$ $(11 / 35 ; 31.4 \%)$ and 16 patients on $\mathrm{D}_{3}(16 / 31 ; 51.6 \%)$. When considering all patients, the correlation $(r S)$ between age and serum vancomycin concentration on $\mathrm{D}_{1}$ was $0.56(P<0.001)$ and between $\mathrm{CL}_{\mathrm{Cr}}$ and $\mathrm{D}_{1}$ serum vancomycin was $-0.57(P<0.001)$ (Fig. 2$)$. To assess the independence of $\mathrm{CL}_{\mathrm{Cr}}$, multiple regression analysis was performed, which showed that this effect was independent of the age and sex of the patient $(P<0.01)$.

\section{Discussion}

This study shows that ARC is strongly associated with subtherapeutic serum vancomycin levels in critically ill patients in the early hyperdynamic stage of severe sepsis, even in the presence of TDM. In addition, in patients with normal $\mathrm{S}_{\mathrm{Cr}}$, ARC is a frequent condition in the critical care setting ( $40 \%$ of septic patients in this study) and identifies a subgroup of younger and less severe critically ill patients.

Several pathological conditions, such as severe sepsis at early stage, burn injuries, acute leukaemia and severe trauma patients, exhibit hyperdynamic status, hypervolaemia and increased cardiac output, leading to augmented blood flow to major organs $[2,12,13]$. Subsequently, increased renal blood flow leads to raised glomerular filtration and raised clearance of renally eliminated drugs such as vancomycin. Some authors have described $\mathrm{CL}_{\mathrm{Cr}}>120 \mathrm{~mL} / \mathrm{min} / 1.73 \mathrm{~m}^{2}$ as a frequent condition in recently 
Table 1

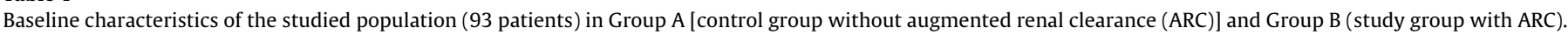

\begin{tabular}{|c|c|c|c|c|}
\hline & All patients $(N=93)$ & Group $\mathrm{A}(N=56)$ & Group B $(N=37)$ & $P$-value \\
\hline Males $[n(\%)]$ & $69(74.2)$ & $40(71.4)$ & $29(78.4)$ & $\mathrm{N} / \mathrm{S}$ \\
\hline Septic shock incidence $[n(\%)]$ & $30(32.3)$ & $20(35.7)$ & $10(27.0)$ & $\mathrm{N} / \mathrm{S}$ \\
\hline Urine output (mL/day) [mean (S.D.)] & $2618(826)$ & $2459(740)$ & $2862(899)$ & $<0.05$ \\
\hline Age (years) [median (IQR)] & $58(34-75)$ & $70(52-79)$ & $41(32-56)$ & $<0.05$ \\
\hline Use of diuretics [n(\%)] & $60(64.5)$ & $35(62.5)$ & $25(67.6)$ & $\mathrm{N} / \mathrm{S}$ \\
\hline Actual body weight $(\mathrm{kg})$ [median (IQR)] & $73.5(65-85)$ & $74(61-80)$ & $77(68.5-88.5)$ & $\mathrm{N} / \mathrm{S}$ \\
\hline APACHE II score [mean (S.D.)] & $17.2(6)$ & $19.1(6)$ & $14.1(5.7)$ & $<0.05$ \\
\hline SAPS II [mean (S.D.)] & $42.2(14.3)$ & $45.9(14)$ & $36.3(12.9)$ & $<0.05$ \\
\hline Serum creatinine $(\mu \mathrm{mol} / \mathrm{L})[$ median $(\mathrm{IQR})]$ & $70.7(61.9-79.6)$ & $70.7(61.9-88.4)$ & $61.9(53-79.6)$ & $\mathrm{N} / \mathrm{S}$ \\
\hline BUN $(\mu \mathrm{mol} / \mathrm{L})[$ median $(\mathrm{IQR})]$ & $8(5.6-10.4)$ & $8.6(6.6-11)$ & $5.7(4.8-8.6)$ & $<0.05$ \\
\hline Serum proteins $(\mathrm{g} / \mathrm{L})$ [median $(\mathrm{IQR})]$ & $53(48-60)$ & $52(47-57)$ & $57(51-62)$ & $<0.05$ \\
\hline Serum albumin $(\mathrm{g} / \mathrm{L})$ [median (IQR)] & $30(25-34)$ & $27(24-31)$ & $32(29-36)$ & $<0.05$ \\
\hline $\mathrm{CL}_{\mathrm{Cr}}\left(\mathrm{mL} / \mathrm{min} / \mathrm{m}^{2}\right)[$ median $(\mathrm{IQR})]$ & $109.6(68.1-152.5)$ & $69.6(57.8-104.2)$ & $158.9(140.9-193.6)$ & $<0.05$ \\
\hline \multicolumn{5}{|l|}{ Admission diagnosis $[n(\%)]$} \\
\hline Trauma & $45(48.4)$ & $23(41.1)$ & $22(59.5)$ & $<0.05$ \\
\hline Sepsis & $28(30.1)$ & $22(39.3)$ & $6(16.2)$ & $<0.05$ \\
\hline Respiratory failure without sepsis & $11(11.8)$ & $8(14.3)$ & $3(8.1)$ & $\mathrm{N} / \mathrm{S}$ \\
\hline Post surgery & $5(5.4)$ & $2(3.6)$ & $3(8.1)$ & $\mathrm{N} / \mathrm{S}$ \\
\hline Other & $4(4.3)$ & $1(1.8)$ & $3(8.1)$ & $\mathrm{N} / \mathrm{S}$ \\
\hline
\end{tabular}

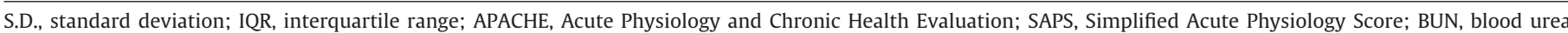
nitrogen; $\mathrm{CL}_{\mathrm{Cr}}$, 24-h creatinine clearance; N/S, not significant (at a level of 0.05 ).

Table 2

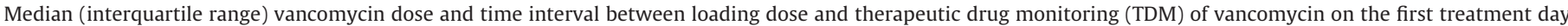
$\left(D_{0}\right)$ for Group A [control group without augmented renal clearance (ARC)] and Group B (study group with ARC).

\begin{tabular}{|c|c|c|c|}
\hline & Group A & Group B & $P$-value \\
\hline Loading dose (g) & $1.0(1.0-1.1)$ & $1.0(1.0-1.5)$ & $\mathrm{N} / \mathrm{S}$ \\
\hline Perfusion dose (g) & $2.0(1.9-2.4)$ & $2.1(2.0-2.4)$ & $\mathrm{N} / \mathrm{S}$ \\
\hline Total dose (g) & $3.1(2.9-3.8)$ & $3.4(3.0-3.9)$ & $\mathrm{N} / \mathrm{S}$ \\
\hline Loading dose/actual weight (mg/kg) & $15.4(12.5-18.2)$ & $14.5(12.5-18.2)$ & $\mathrm{N} / \mathrm{S}$ \\
\hline Perfusion dose/actual weight (mg/kg) & $30(26.7-34.4)$ & $30(25.0-32.3)$ & $\mathrm{N} / \mathrm{S}$ \\
\hline Total dose/actual weight ( $\mathrm{mg} / \mathrm{kg})$ & $47.7(40.0-51.8)$ & $45.4(38.8-48.6)$ & $\mathrm{N} / \mathrm{S}$ \\
\hline Time interval between loading dose and TDM of vancomycin on $\mathrm{D}_{0}(\mathrm{~h})$ & $17(16-17)$ & $17(17-18)$ & $\mathrm{N} / \mathrm{S}$ \\
\hline
\end{tabular}

$\mathrm{N} / \mathrm{S}$, not significant (at a level of 0.05 ).

admitted critically ill patients (17.9\%), increasing to rates as high as $30 \%$ during the first week of admission [11]. Accordingly, serum and tissue subtherapeutic drug levels are the pharmacological consequences, contributing to treatment failure of severe infections. This condition, here defined as ARC, is unappreciated in the critical care setting and is under-reported in the medical literature, and can be a co-factor responsible for inadequate antibiotic prescription

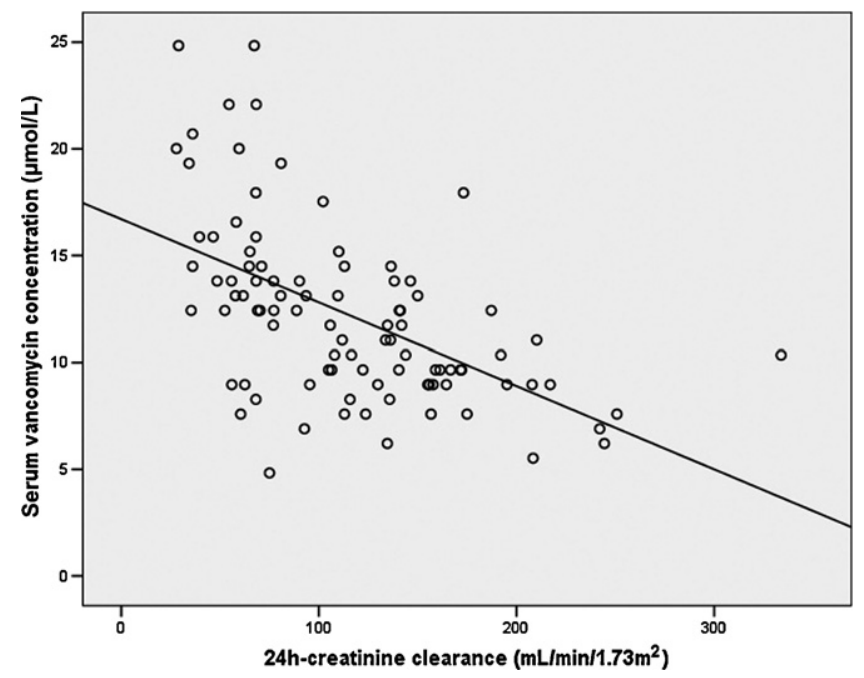

Fig. 2. Linear correlation between 24 -h creatinine clearance $\left(\mathrm{CL}_{\mathrm{Cr}}\right)$ and serum vancomycin concentration on Day 1 . The serum vancomycin concentration displayed a significant direct correlation with $\mathrm{CL}_{\mathrm{Cr}}$ in 93 septic critically ill patients $(r S=-0.57$; $P<0.01)$. despite adequate recommended dosage and respective adjustment to body weight. One of the particularities of the current data was that a group of patients in which renal clearance was actually measured, and not estimated, was studied. A previous study has shown that in critically ill patients exhibiting ARC, estimates of GFR are insensitive in identifying this phenomenon [14].

Vancomycin is a hydrophilic drug with predominantly renal excretion (80-90\%), whose clearance correlates with $\mathrm{CL}_{\mathrm{Cr}}[15,16]$. It shows time-dependent activity that, in turn, is linked to the ratio of the 24-h area under the concentration-time curve $\left(\mathrm{AUC}_{24}\right)$ to MIC. As shown in Fig. 1, the serum vancomycin concentration in Group $B$ just reached, on average, therapeutic levels on D3 $(13.8 \mu \mathrm{mol} / \mathrm{L})$. Actually, only $52 \%$ of patients (16/31) reached minimal therapeutic serum levels, meaning that approximately one-half of the patients have not yet started optimal treatment of infection on D3, in other words only $72 \mathrm{~h}$ after the vancomycin loading dose. These results are in agreement with another recent study in which the authors found that in critically ill patients a higher dose of vancomycin in continuous infusion than usual is needed, following an adequate loading dose, to achieve a target plateau concentration of $17.3 \mu \mathrm{mol} / \mathrm{L}(25 \mu \mathrm{g} / \mathrm{mL})[17]$.

Patients in both groups, on average, were treated with an equivalent total amount of vancomycin (loading plus maintenance dose) during the $24 \mathrm{~h}$ of $\mathrm{D}_{0}$ (Table 2 ). A very high rate of subtherapeutic serum vancomycin concentration was observed on $D_{1}$, mostly in Group B (89\%) but also in Group A (53\%). This last result was unexpected since Group A had $28.6 \%$ of patients (16/56) with $\mathrm{CL}_{\mathrm{Cr}}<60 \mathrm{~mL} / \mathrm{min} / 1.73 \mathrm{~m}^{2}$. It is possible that, in these patients without ARC, other factors such as hypoalbuminaemia and increased volume of distribution $\left(V_{\mathrm{d}}\right)$, could contribute to this low therapeutic level on $D_{1}$. Serum albumin, a major determinant of $V_{d}$, was 
significantly higher in patients with ARC (Group B), an event that is not surprising since this group was younger, less severely ill and with a higher potential physiological reserve. Moreover, vancomycin is not a highly albumin-bound drug (30-55\%) so it should not greatly influence vancomycin availability; however, even for hydrophilic antibiotics with low albumin binding, increased $V_{\mathrm{d}}$ has been described $[18,19]$.

Although we have analysed a considerable number of patients ( $n=93$ ), the main limitation of the present study lies in the fact that it is a single-centre study, reflecting the case mix of our ICU, namely with a significant trauma population. Furthermore, the $\mathrm{CL}_{\mathrm{Cr}}$ measurement is laborious and this factor could be a bias for imperfect urine collection, thus leading to clearance miscalculations. Finally, $V_{\mathrm{d}}$ was not assessed in this study, thus the discussion around this issue is merely speculative.

In conclusion, amongst critically ill patients with normal $\mathrm{S}_{\mathrm{Cr}}$, ARC is strongly associated with subtherapeutic serum vancomycin levels and this study clearly shows the need to use a more aggressive initial loading dose as well as TDM in these particular patients. ARC appears to be a relatively frequent occurrence in this setting, namely in young males with trauma and less severe disease.

Funding: No funding sources.

Competing interests: None declared.

Ethical approval: This study was approved by the Institutional Review Board of the Committee of the Innovation and Development Unit, Coimbra University Hospital (Coimbra, Portugal) (Project Approval No. 42/IDU/10/D).

\section{References}

[1] Roberts JA, Lipman J. Pharmacokinetic issues for antibiotics in the critically ill patient. Crit Care Med 2009;37:840-51.

[2] Fry DE. The importance of antibiotic pharmacokinetics in critical illness. Am J Surg 1996;172:20S-5S.

[3] Pinder M, Bellomo R, Lipman J. Pharmacological principles of antibiotic prescription in the critically ill. Anaesth Intensive Care 2002;30:134-44.
[4] Moise PA, Schentag JJ. Vancomycin treatment failures in Staphylococcus aureus lower respiratory tract infections. Int J Antimicrob Agents 2000;16(Suppl. 1):S31-4.

[5] Levy MM, Fink MP, Marshall JC, Abraham E, Angus D, Cook D, et al. SCCM/ESICM/ACCP/ATS/SIS. 2001 SCCM/ESICM/ACCP/ATS/SIS International Sepsis Definitions Conference. Crit Care Med 2003;31:1250-6.

[6] Rybak MJ, Lomaestro BM, Rotschafer JC, Moellering RC, Craig WA, Billeter M et al. Therapeutic monitoring of vancomycin in adults: summary of consensus recommendations from the American Society of Health-System Pharmacists, the Infectious Diseases Society of America, and the Society of Infectious Diseases Pharmacists. Pharmacotherapy 2009;29:1275-9.

[7] Medicines and Healthcare Products Regulatory Agency (MHRA). http:// www.mhra.gov.uk/home/groups/par/documents/websiteresources/con131955 .pdf [accessed 20 January 2012].

[8] Wesson L. Physiology of the human kidney. New York, NY: Grune \& Stratton; 1969.

[9] Udy A, Roberts JA, Boots RJ, Paterson DL, Lipman J. Augmented renal clearance implications for antibacterial dosing in the critically ill. Clin Pharmacokinet 2010;49:1-16.

[10] Sunder-Plassmann G, Horl WH. A critical appraisal for definition of hyperfiltration. Am J Kidney Dis 2004;43:396.

[11] Fuster-Lluch O, Gerónimo-Pardo M, Peyró-García R, Lizán-García M. Glomerular hyperfiltration and albuminuria in critically ill patients. Anaesth Intensive Care 2008;36:674-80.

[12] Weinbren MJ. Pharmacokinetics of antibiotics in burns patients. J Antimicrob Chemother 1999;44:319-27.

[13] Chang D. Influence of malignancy on the pharmacokinetics of vancomycin in infants and children. Pediatr Infect Dis J 1995;14:667-73.

[14] Baptista JP, Udy AA, Sousa E, Pimentel J, Wang L, Roberts JA, et al. A comparison of estimates of glomerular filtration in critically ill patients with augmented renal clearance. Crit Care 2011;15:R139.

[15] Kees MG, Hilpert JW, Gnewuch C, Kees F, Voegeler S. Clearance of vancomycin during continuous infusion in Intensive Care Unit patients: correlation with measured and estimated creatinine clearance and serum cystatin C. Int J Antimicrob Agents 2010;36:545-8.

[16] Soy D, Torres A. Antibacterial dosage in intensive-care-unit patients based on pharmacokinetic/pharmacodynamic principles. Curr Opin Crit Care 2006;12:477-82.

[17] Jeurissen A, Sluyts I, Rutsaert R. A higher dose of vancomycin in continuous infusion is needed in critically ill patients. Int J Antimicrob Agents 2010;37:75-7.

[18] Romano S, Del Mar Fdez de Gatta M, Calvo V, Mendez E, Domínguez-Gil A Lanao JM. Influence of clinical diagnosis in the population pharmacokinetics of amikacin in intensive care unit patients. Clin Drug Investig 1998;15:435-44.

[19] Taccone FS, Laterre PF, Dugernier T, Spapen H, Delattre I, Witebolle X, et al. Insufficient $\beta$-lactam concentrations in the early phase of severe sepsis and septic shock. Crit Care 2010;14:R126. 